\title{
Growth Hormone Releasing Hormone Receptors Antagonists and Cancers: Do GHRH-R Antagonists Play a Role in the Management of Prostate Cancer?
}

\author{
Joseph Bertin Alexis Zoa Bindzi1,2*, Yingjie Yang1,2, Xiaoqi Yan³, Yi Zhong3*, Yuantong Tian1,2* \\ ${ }^{1}$ Pharmacology Department of Gannan Medical University, Ganzhou, China \\ ${ }^{2}$ Key Laboratory of Prevention and Treatment of Cardiovascular and Cerebrovascular Diseases of Ministry of Education, \\ Ganzhou, China \\ ${ }^{3}$ Urology Department of the First Affiliate Hospital of Gannan Medical University, Ganzhou, China \\ Email: ${ }^{* 1918093836 @ q q . c o m ~}$
}

How to cite this paper: Zoa Bindzi, J.B.A., et al. (2020) Growth Hormone Releasing Hormone Receptors Antagonists and Cancers: Do GHRH-R Antagonists Play a Role in the Management of Prostate Cancer? Open Journal of Urology, 10, 201-210. https://doi.org/10.4236/oju.2020.106023

Received: April 28, 2020

Accepted: May 25, 2020

Published: May 28, 2020

Copyright $\odot 2020$ by author(s) and Scientific Research Publishing Inc. This work is licensed under the Creative Commons Attribution International License (CC BY 4.0).

http://creativecommons.org/licenses/by/4.0/

\begin{abstract}
Growth hormone-releasing hormone (GHRH) and its receptors have been implicated in the progression of various tumors such as those of the prostate. Treatment modalities for prostate cancer in a localized stage or when it is still castration-sensitive yield good results in most patients. However, such treatments are only palliative in the advanced stage. Therefore, new therapeutic targets like growth hormone-releasing hormone receptor (GHRH-R) and its splice variants should be found in order to get effective treatments for more aggressive stages in prostate cancer. This review talks about the GHRH-R and its splice variants, the signaling pathways induced by GHRH to produce cancer, the structure activity relationship of GHRH-R antagonists and the resume of some in vitro and in vivo studies on the role of GHRH-R antagonists in the treatment of prostate cancer.
\end{abstract}

\section{Keywords}

GHRH, Receptors, Antagonists, Prostate, Cancer

\section{Introduction}

In spite of the impressive progress in diagnosis, surgery, and chemotherapy, prostate cancer is still the second most common cancer and the fourth leading cause of cancer death among men in China [1]. Considering the disadvantages of standard treatments for prostate cancer in their late stage, it's crucial to ex- 
plore new therapeutic strategies for advanced prostate cancer with less or no side-effects and to substitute the palliative treatment. In addition to its endocrine role, the GHRH has been shown to act as a growth factor driving the progress of cancer in diverse malignancies including prostate cancer [2]. Therefore, the molecular changes in prostate carcinogenesis induced by GHRH make GHRH-R and its splice variants (Figure 1) therapeutic targets for patients with advanced prostate cancer.

\section{GHRH-R and Its Splices Variants in Human Prostate Cancers}

Besides the pituitary type of GHRH-R, some studies have described GHRH-R splice variants (SVs) in human prostate cancers [3] [4]. From these studies we noted that SV1 is present in $65 \%$ of the human prostate cancers. A major part of the nucleotide sequence of SV1 has more than 99\% identity with the corresponding sequence of pituitary GHRH-R cDNA [5]. SV2 is shown in $60 \%$ of prostate cancer specimens. SV2 most likely encodes a GHRH receptor isoform truncated after the second transmembrane domain [5]. The deduced protein sequences of SV1 and SV2 suggest that they possess a distinct 25-amino acid sequence at the $\mathrm{N}$-terminal extracellular domain, which could serve as a signal peptide. The expression of SV4 is about $15 \%$. The short protein sequence corresponding to SV4 lacks all transmembrane domains, implying that it is not expressed on the cell surface. After PCR amplification, it has been detected a novel SV of GHRH receptor in prostate cancer in which exons 5 and 6 are missing, whereas exon 7 is retained [5].

GHRH receptor isoform encoded by SV1 could mediate the effect of GHRH and its antagonists on extrapituitary cells and various tumors [4]. These SVs forms have demonstrated both ligand-dependent and independent activities [2] [6].

\section{Physiological Action of GHRH as a Protumoral Agent}

Pituitary type GHRH receptor (pGHRH-R), is a class II G-protein-coupled receptor with seven transmembrane domains and is homologous with the receptors for vasoactive intestinal peptide (VIP), pituitary adenylate cyclase activating peptide (PACAP) and calcitonin [7]. Activation of the G-protein complex stimulates adenyl cyclase, which results in the conversion of ATP to cAMP. cAMP, functioning as second messenger in the GHRH signal transduction, induces phosphorylation of intracellular and membrane-associated proteins and leads to IGF-I secretion (a known mitogen) from the liver [8]. At the level of the mechanism of GHRH action, it is important to identify the specific receptors in which the local effects of GHRH are mediated and to define the network of the proliferative and non-proliferative consequences of GHRH action. The elucidation of the downstream targets that follow receptor binding and activation will shed light on how GHRH exerts its mitogenic effects. The stage of tumorigenesis with which GHRH production is associated, being briefly the initiation, promotion and maintenance of cancer, also remain an open question. 


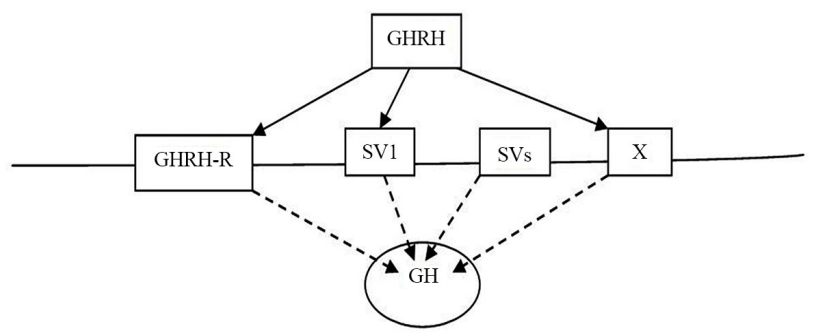

Figure 1. Representation of the action of GHRH. The effects of GHRH are mediated by GHRH-R, SV1, and probably others receptors (X), which may include the receptors of VIP and PACAP.

\section{Pathological Action of GHRH: Signaling Pathways Involved in Tumoral Process}

As a ligand-bound G-protein coupled receptors, GHRH can activate cytoplasmic heterotrimeric G-proteins whose a subunit responds by exchanging its GDP for GTP. The Ga subunit activates its own effectors, including the Ras-Raf-MEK-ERK pathway also called MAPKs pathway, the Ras-PBK-Akt pathway, the Jak/STATs pathway. All these pathways are linked to cell differentiation, proliferation, metabolic changes and cell migration [9]. It is known that G-protein coupled receptors are able to activate tyrosine kinase receptors [10]. So GHRH is also involved in the transactivation of the signaling of epidermal growth factor receptor (EGFR/HER1/ErbB1) and human epidermal growth factor receptor-2 (HER2) in prostate cancer [11].

In the figure (Figure 2), GHRH can bind directly to GHRH-Rs on multiple cell types of endocrine and nonendocrine origin. Signaling pathways that are activated by GHRH and its agonists include AC/cAMP/PKA, Ras/Raf/ERK, PI3K/Akt, and STAT3. Mediation through these signaling pathways leads to enhanced cell survival, proliferation, and secretion of cytokines. GHRH antagonists inhibit these pathways by competitively binding to the GHRH-R.

\section{GHRH-R Antagonists}

GHRH-R has been considered as a potential therapeutic target for cancer in recent years. Several GHRH-R antagonists have been used experimentally against cancers; the theory of using GHRH-R antagonists is suggested to be discussed. We can enumerate some GHRH-R antagonists: earlier GHRH-R antagonists (MZ-4-71 and MZ-5-156), JV-1-series (38, 63, 65, 68, 80), MZ-J-7-series (114, 118,138 and 132) and the MIAMI-series (602, 604, 606, 610, 640 and 690). JV-1-63 is one of the more potent endocrine antagonist of GHRH reported to date again human prostatic growth [12]. The theory of using GHRH-R antagonists is suggested to be discussed.

\subsection{Structure Activity Relationship of GHRH-R Antagonists}

Early studies revealed that replacement of $A l a^{2}$ in GHRH by $D-A l a^{2}$ or $N$-methyl-D-Ala lad to superpotent agonist while the replacement by $D-A r g^{2}$ 


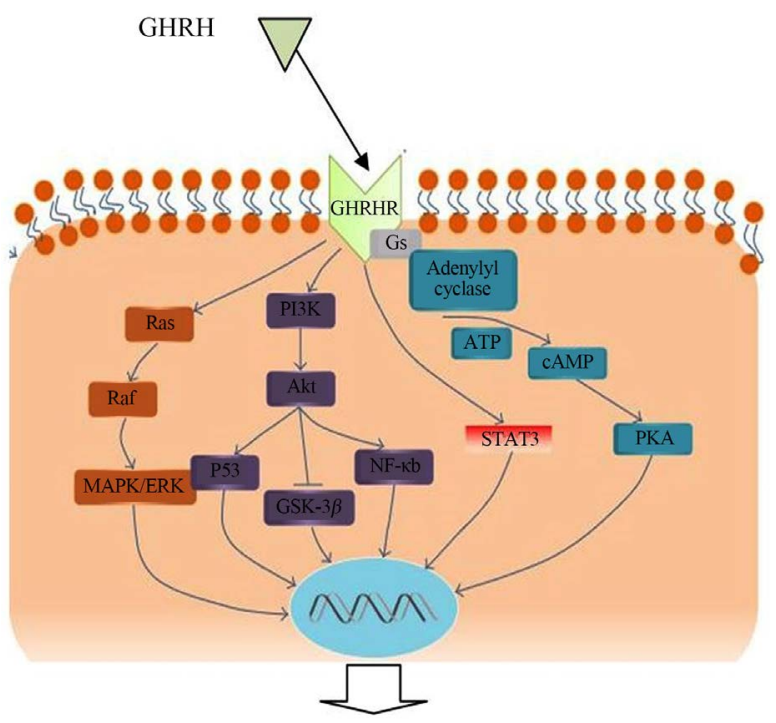

$\downarrow$ APOPTOSIS, $\uparrow$ PROLIFERATION, $\uparrow$ ANGIOGENESIS, $\uparrow$ SECRETION

Figure 2. Schematic illustration of pathological activity of GHRH.

produce antagonists [13]. Chemical modifications tend to increase the selectivity of new series of GHRH-R antagonists because they exhibit increased antitumor effects in vivo on human experimental prostatic cancer but weaker endocrine effects on the inhibition of hepatic IGF-1 in serum as compared to earlier antagonists such as MZ-4-71 or MZ-5-156 [14] [15] [16] [17].

More than $20 \%$ of pharmaceuticals now contain one or more fluorine atoms [18]. The novel analogs designated "MIA" have been designed by incorporating pentafluoro-Phe at different positions into the previous MZ-J-7-series and the JMR-132 antagonist. This resulted to an increased anti-cancer activity compared to earlier JV-series. It has been recognized that the presence of fluorine in compounds results in metabolic stability [19] leading to improved bioactivity and bioavailability [20].

\subsection{GHRH-R Antagonists Effects in Prostate Cancer}

The anti-tumor effects of GHRH antagonists can be mediated through direct mechanisms. One of these mechanisms is based upon the inhibition of the secretion of autocrine/paracrine IGF-I or IGF-II from the tumors; the most important pathway involves the blockade of action of autocrine GHRH in tumors. The anti-tumor activity of GHRH antagonists is especially important oncologically because of the wide expression of the intrinsic GHRH and SVs of GHRH-R in various cancers. We can share some results of recent studies:

1) In a study carried by Nektarios Barabutis and Andrew Schally (2008) on the inhibition of human cancer cell line by knocking down gene expression for GHRH, they found that of In this study, the proliferation rate of prostate cancer cell lines (LNCap) were decreased by $26 \%-37 \%$ and $31-42 \%$ after exposure to GHRH-R antagonists MZ-4-71, MZ-5-156 and JMR-132 at concentration of 0.1 and $1 \mu \mathrm{M}$ respectively [21]; 
2) In a study carried on nude mice with objective the inhibition of the orthotopic and metastatic growth of PC-3 human androgen-independent prostate cancers by GHRH-R antagonists (MZ-4-71 and MZ-5-156), bombesin and gastrin releasing peptide; Anton Stangelberger et al. (2005) found that the growth of subcutaneous xenografts of human androgen independent PC-3 prostate cancers was inhibited by high dose (20 $\mu$ g b.i.d.) of MZ-4-71 and MZ-5-156 or much lower dose $(2.5-5 \mu \mathrm{g} /$ day $)$ of new and more potent antagonists MZ-J-7-118 and MZ-J-7-138 [14] [17]. GHRH-R antagonists also inhibited the orthotopic growth of PC3 tumors [17];

3) Andrew Schally et al. in these studies found that, given alone, GHRH antagonists JV-1-38 (20 $\mu \mathrm{g} /$ day) or MZ-J-7-118 (5 $\mu \mathrm{g} /$ day) were ineffective for the treatment of prostate cancers LNCaP and MDA-PCa- $2 \mathrm{~b}$, but they greatly enhanced the inhibitory effects of androgen deprivation therapies such as surgical castration and LHRH agonists or antagonists on the growth of subcutaneous and orthotopic prostate tumor [22] [23] [24];

4) Kanashiro et al. in three studies demonstrated that GHRH-R antagonists inhibit the PKC-MAPKs and PBK-Akt signaling pathways, decrease the expression of cjun and $c$-fos oncogenes, and mutant $p 53$ protein levels in human prostate cancer models [25] [26] [27]. In addition GHRH-R antagonists decrease anti apoptotic $B c l-2$ and increase pro apoptotic Bax protein in the prostate cancer line LNCaP. They trigger a $\mathrm{Ca}^{2+}$ dependent apoptotic mechanism;

5) Laura Muñoz-Moreno et al. (2016) found in this study that, GHRH-R antagonists JMR-132 and JV-1-38 suppressed cell proliferation and decreased the levels of the proliferation marker, PCNA, in the three cell lines (non-tumoral RWPE-1 and tumoral LNCaP and PC3 human prostatic epithelial cells) and in PC3 tumor. They led to an increase of cells in S-phase and a decrease in G1 and G2/M phases, and induced S-phase arrest and significant increase ( $p<0.001$ vs. control) of apoptotic cells like p53, p21 and bax [28];

6) In a study carried by Nektarios Barabutis and Andrew Schally (2008) on the antioxidant activity of growth hormone-releasing hormone antagonists in LNCaP human prostate cancer line, they found that GHRH antagonist, JMR-132, inhibited the expression of the major antioxidant enzymes (GPx1, SOD1, NQO1, and Trx1), as well as the expression of COX 2 and cytochrome c oxidase IV, which are enzymes involved in the generation of ROS. It also suppressed lipid and protein oxidative stress markers, as well as the intracellular generation of ROS. They also noted that the activation of the NF- $\mathrm{kB}$ p50, which promotes carcinogenesis, is enhanced by oxidative stress and cells exposed to JMR-132 expressed lower levels of pNF-kB [29];

7) This study carried by Laura Muñoz-Moreno et al. (2018) was performed in three human prostate cell lines (RWPE-1, LNCaP and PC3). In this study, GHRH-R antagonists (MIA-602, MIA-606, and MIA-690) decreased cell viability and provoked a reduction in proliferation in LNCaP and PC3 cells. They reduced $\beta$-catenin levels in the nucleus preventing the activation of transcription 


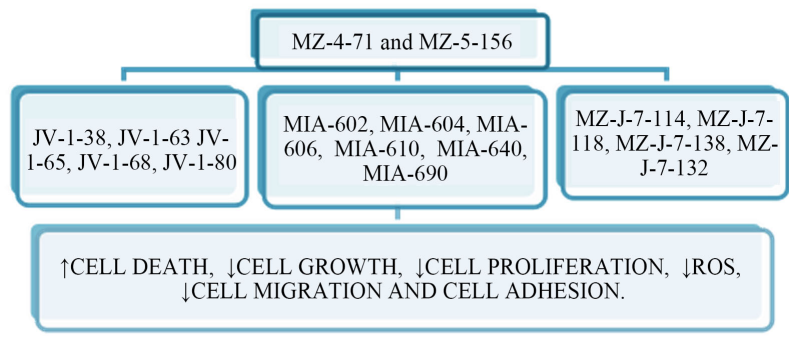

Figure 3. Pictorial representation of GHRH-R antagonist's activities.

of target genes, $c$-myc, cyclin $D 1$, and $C D 44$ with the highest value with MIA-690 in PC3 cells. VEGF (vascular endothelial growth factor) which is related to molecules involved in migration and adhesion as $\beta$-catenin or MMPs 9 and 2 (matrix metallopeptidase) protein levels were decreased by $31 \%$ after treatment with MIA-602, MIA-606, and MIA-690 as compared to control ( $\beta$-actin antibody) [30].

Figure 3 summarizes the effects of GHRH receptor antagonists. The synthesis of the new series of GHRH receptor antagonists comes from chemical modifications of the first two molecules (MZ-4-71 and MZ-5-156). The new series thus present a more pronounced anticancer activity.

\section{Conclusion}

According to current existing literature, GHRH-R antagonists could be defined as inhibitors of tumor progression in prostate cancer and should be considered for use in future therapeutic strategies. Our review supports the merit of development of GHRH-R antagonists for the clinical therapy of prostate cancer. We think that other signal transduction mechanisms arise from those mediated by cAMP may also mediate the effect of GHRH, so combination therapies that target all the pathways involved in the pathogenesis of prostate cancer should increase the efficacy of future. An example could be the use of GHRH-R antagonists in association with a monoclonal antibody that target the EGFR.

\section{Authors' Contributions}

All the authors read and approved the final version of the manuscript.

\section{Funding}

Not applicable.

\section{Availability of Data and Materials}

Data sharing is not applicable to this article as no datasets were generated or analyzed during the current study.

\section{Ethics Approval and Consent to Participate}

Not applicable. 


\section{Consent for Publication}

Not applicable.

\section{Acknowledgements}

This work was supported by grants from the National Natural Science Foundation of China (81560422), the Natural Science Foundation of Jiangxi of China (20151BAB205016), the Key Project of Science and Technology from Department of Education of Jiangxi Province (GJJ190787) and the Gannan Medical College Innovation Team Project (TD2-1703).

\section{Conflicts of Interest}

The authors declare no conflicts of interest regarding the publication of this paper.

\section{References}

[1] Rawla, P. (2019) Epidemiology of Prostate Cancer. World Journal of Oncology, 10, 63-89. https://doi.org/10.14740/wjon1191

[2] Barabutis, N. and Schally, A.V. (2010) Growth Hormone-Releasing Hormone: Extrapituitary Effects in Physiology and Pathology. Cell Cycle, 9, 4110-4116. https://doi.org/10.4161/cc.9.20.13787

[3] Havt, A., Schally, A.V., Halmos, G., Varga, J.L., Toller, G.L., Horvath, J.E., et al. (2005) The Expression of the Pituitary Growth Hormone-Releasing Hormone Receptor and Its Splice Variants in Normal and Neoplastic Human Tissues. Proceedings of the National Academy of Sciences of the United States of America, 102, 17424-17429. https://doi.org/10.1073/pnas.0506844102

[4] Halmos, G., Schally, A.V., Czompoly, T., Krupa, M., Varga, J.L. and Rekasi, Z. (2002) Expression of Growth Hormone-Releasing Hormone and Its Receptor Splice Variants in Human Prostate Cancer. The Journal of Clinical Endocrinology \& Metabolism, 87, 4707-4714. https://doi.org/10.1210/jc.2002-020347

[5] Rekasi, Z., Czompoly, T., Schally, A.V. and Halmos, G. (2000) Isolation and Sequencing of cDNAs for Splice Variants of Growth Hormone-Releasing Hormone Receptors from Human Cancers. Proceedings of the National Academy of Sciences of the United States of America, 97, 10561-10566.

https://doi.org/10.1073/pnas.180313297

[6] Kiaris, H., Chatzistamou, I., Schally, A.V., Halmos, G., Varga, J.L., Koutselini, H., et al. (2003) Ligand-Dependent and -Independent Effects of Splice Variant 1 of Growth Hormone-Releasing Hormone Receptor. Proceedings of the National Academy of Sciences of the United States of America, 100, 9512-9517. https://doi.org/10.1073/pnas.1533185100

[7] DeAlmeida, V.I. and Mayo, K.E. (2001) The Growth Hormone-Releasing Hormone Receptor. Vitamins and Hormones, 63, 233-276. https://doi.org/10.1016/S0083-6729(01)63008-5

[8] Mayo, K.E., Miller, T.L., DeAlmeida, V., Zheng, J. and Godfrey, P.A. (1996) The Growth-Hormone-Releasing Hormone Receptor: Signal Transduction, Gene Expression, and Physiological Function in Growth Regulation. Annals of the New York Academy of Sciences, 805, 184-203. 
https://doi.org/10.1111/j.1749-6632.1996.tb17483.x

[9] Mayo, K.E., Miller, T., DeAlmeida, V., Godfrey, P., Zheng, J. and Cunha, S.R. (2000) Regulation of the Pituitary Somatotroph Cell by GHRH and Its Receptor. Recent Progress in Hormone Research, 55, 237-266.

[10] Delcourt, N., Bockaert, J. and Marin, P. (2007) GPCR-Jacking: From a New Route in RTK Signalling to a New Concept in GPCR Activation. Trends in Pharmacological Sciences, 28, 602-607. https://doi.org/10.1016/j.tips.2007.09.007

[11] Munoz-Moreno, L., Arenas, M.I., Carmena, M.J., Schally, A.V., Prieto, J.C. and Bajo, A.M. (2014) Growth Hormone-Releasing Hormone Antagonists Abolish the Transactivation of Human Epidermal Growth Factor Receptors in Advanced Prostate Cancer Models. Investigational New Drugs, 32, 871-882.

https://doi.org/10.1007/s10637-014-0131-4

[12] Varga, J.L., Schally, A.V., Horvath, J.E., Kovacs, M., Halmos, G., Groot, K., et al. (2004) Increased Activity of Antagonists of Growth Hormone-Releasing Hormone Substituted at Positions 8, 9, and 10. Proceedings of the National Academy of Sciences of the United States of America, 101, 1708-1713.

https://doi.org/10.1073/pnas.0307288101

[13] Schally, A.V. and Varga, J.L. (1999) Antagonistic Analogs of Growth Hormone-Releasing Hormone: New Potential Antitumor Agents. Trends in Endocrinology \& Metabolism, 10, 383-391. https://doi.org/10.1016/S1043-2760(99)00209-X

[14] Stangelberger, A., Schally, A.V., Varga, J.L., Hammann, B.D., Groot, K., Halmos, G., et al. (2005) Antagonists of Growth Hormone Releasing Hormone (GHRH) and of Bombesin/Gastrin Releasing Peptide (BN/GRP) Suppress the Expression of VEGF, bFGF, and Receptors of the EGF/HER Family in PC-3 and DU-145 Human Androgen-Independent Prostate Cancers. Prostate, 64, 303-315.

https://doi.org/10.1002/pros.20262

[15] Engel, J.B., Keller, G., Schally, A.V., Toller, G.L., Groot, K., Havt, A., et al. (2005) Inhibition of Growth of Experimental Human Endometrial Cancer by an Antagonist of Growth Hormone-Releasing Hormone. The Journal of Clinical Endocrinology \& Metabolism, 90, 3614-3621. https://doi.org/10.1210/jc.2004-2179

[16] Keller, G., Schally, A.V., Groot, K., Toller, G.L., Havt, A., Köster, F., et al. (2005) Effective Treatment of Experimental Human Non-Hodgkin's Lymphomas with Antagonists of Growth Hormone-Releasing Hormone. Proceedings of the National Academy of Sciences of the United States of America, 102, 10628-10633. https://doi.org/10.1073/pnas.0504102102

[17] Stangelberger, A., Schally, A.V., Varga, J.L., Zarandi, M., Szepeshazi, K., Armatis, P., et al. (2005) Inhibitory Effect of Antagonists of Bombesin and Growth Hormone-Releasing Hormone on Orthotopic and Intraosseous Growth and Invasiveness of PC-3 Human Prostate Cancer in Nude Mice. Clinical Cancer Research, 11, 49-57.

[18] Filler, R. and Saha, R. (2009) Fluorine in Medicinal Chemistry: A Century of Progress and a 60-Year Retrospective of Selected Highlights. Future Medicinal Chemistry, 1, 777-791. https://doi.org/10.4155/fmc.09.65

[19] Park, B.K., Kitteringham, N.R. and O’Neill, P.M. (2001) Metabolism of Fluorine-Containing Drugs. Annual Review of Pharmacology and Toxicology, 41, 443-470. https://doi.org/10.1146/annurev.pharmtox.41.1.443

[20] Asante, V., Mortier, J., Schlüter, H. and Koksch, B. (2013) Impact of Fluorination on Proteolytic Stability of Peptides in Human Blood Plasma. Bioorganic \& Medicinal Chemistry, 21, 3542-3546. https://doi.org/10.1016/j.bmc.2013.03.051 
[21] Barabutis, N. and Schally, A.V. (2008) Knocking Down Gene Expression for Growth Hormone-Releasing Hormone Inhibits Proliferation of Human Cancer Cell Lines. British Journal of Cancer, 98, 1790-1796. https://doi.org/10.1038/sj.bjc.6604386

[22] Letsch, M., Schally, A.V., Busto, R., Bajo, A.M. and Varga, J.L. (2003) Growth Hormone-Releasing Hormone (GHRH) Antagonists Inhibit the Proliferation of Androgen-Dependent and -Independent Prostate Cancers. Proceedings of the National Academy of Sciences of the United States of America, 100, 1250-1255. https://doi.org/10.1073/pnas.0337496100

[23] Letsch, M., Schally, A.V., Stangelberger, A., Groot, K. and Varga, J.L. (2004) Antagonists of Growth Hormone-Releasing Hormone (GH-RH) Enhance Tumour Growth Inhibition Induced by Androgen Deprivation in Human MDA-Pca-2b Prostate Cancers. European Journal of Cancer, 40, 436-444. https://doi.org/10.1016/j.ejca.2003.10.010

[24] Schally, A.V., Comaru-Schally, A.M., Nagy, A., Kovacs, M., Szepeshazi, K., Plonowski, A., et al. (2001) Hypothalamic Hormones and Cancer. Frontiers in Neuroendocrinology, 22, 248-291. https://doi.org/10.1006/frne.2001.0217

[25] Kanashiro, C.A., Schally, A.V., Groot, K., Armatis, P., Bernardino, A.L. and Varga, J.L. (2003) Inhibition of Mutant p53 Expression and Growth of DMS-153 Small Cell Lung Carcinoma by Antagonists of Growth Hormone-Releasing Hormone and Bombesin. Proceedings of the National Academy of Sciences of the United States of America, 100, 15836-15841. https://doi.org/10.1073/pnas.2536558100

[26] Kanashiro, C.A., Schally, A.V., Zarandi, M., Hammann, B.D. and Varga, J.L. (2004) Suppression of Growth of H-69 Small Cell Lung Carcinoma by Antagonists of Growth Hormone Releasing Hormone and Bombesin Is Associated with an Inhibition of Protein Kinase C Signaling. International Journal of Cancer, 112, 570-576. https://doi.org/10.1002/ijc.20437

[27] Kiaris, H., Koutsilieris, M., Kalofoutis, A. and Schally, A.V. (2003) Growth Hormone-Releasing Hormone and Extra-Pituitary Tumorigenesis: Therapeutic and Diagnostic Applications of Growth Hormone-Releasing Hormone Antagonists. EXpert Opinion on Investigational Drugs, 12, 1385-1394. https://doi.org/10.1517/13543784.12.8.1385

[28] Munoz-Moreno, L., Arenas, M.I., Carmena, M.J., Schally, A.V., Sanchez-Chapado, M., Prieto, J.C., et al. (2016) Anti-Proliferative and Pro-Apoptotic Effects of GHRH Antagonists in Prostate Cancer. Oncotarget, 7, 52195-52206. https://doi.org/10.18632/oncotarget.10710

[29] Barabutis, N. and Schally, A.V. (2008) Antioxidant Activity of Growth Hormone-Releasing Hormone Antagonists in LNCaP Human Prostate Cancer Line. Proceedings of the National Academy of Sciences of the United States of America, 105, 20470-20475. https://doi.org/10.1073/pnas.0811209106

[30] Munoz-Moreno, L., Schally, A.V., Prieto, J.C., Carmena, M.J. and Bajo, A.M. (2018) Growth Hormone-Releasing Hormone Receptor Antagonists Modify Molecular Machinery in the Progression of Prostate Cancer. Prostate, 78, 915-926. https://doi.org/10.1002/pros.23648 


\section{Abbreviations}

GHRH-R: Growth hormone releasing hormone receptors; cAMP: cyclic Adenosine monophosphate;

VIP: Vasoactive intestinal peptide;

PACAP: Pituitary adenylate cyclase activating peptide;

IGF-1: Insulin-like growth factor 1 ;

CDKN2: Cyclin dependent kinase inhibitor 2;

ERK: Extracellular signal-regulated kinase;

MAPKs: Mitogen-activated protein kinases;

Jak: Janus activated kinase;

STATs: Signal transducers and activators of transcription;

EGFR: Epidermal growth factor receptor;

HER: Human epidermal growth factor receptor;

PCR: Polymerase chain reaction;

ROS: Oxygen reactive species 